\title{
ARDL panel estimation of stock market indices and macroeconomic environment of CEE and SEE countries in the last decade of transition
}

\author{
Anita Radman Peša ${ }^{1}$ \& Elżbieta Wrońska-Bukalska ${ }^{2}$ \& \\ Jurica Bosna ${ }^{1}$
}

Received: 25 July 2016 / Accepted: 26 April 2017 /Published online: 11 May 2017

\# ISEG 2017

\begin{abstract}
We tested the hypothesis of the procyclicality of stock exchanges regarding the economic activity of CEE and SEE countries, to measure the level of financial integration during the last decade of the transition period, and to compare these two groups of emerging countries. Our ARDL panel estimates support the hypothesis of procyclicality in the transition period in the CEE and SEE regions, and further financial integration, due to the opening up of the market economy and repricing of systematic risk, followed by large capital inflows, trade liberalization and industrial production, along with the implementation of institutional reforms regarding EU integration. In addition, the significant positive coefficient of capital inflows and negative coefficient of unemployment rate in the CEE and SEE panel ARDL results confirm the volatility of the transition process, as is obvious in higher industrial production, followed by the significant impact of import on CEE countries and the much higher significant impact of export on SEE countries.
\end{abstract}

Keywords Panel estimation · Stock exchange $\cdot$ Central and Eastern Europe $\cdot$ South East Europe $\cdot$ Financial integration

JEL classifications $\mathrm{E} 44 \cdot \mathrm{F} 36 \cdot \mathrm{F} 43 \cdot \mathrm{G} 1$

Jurica Bosna

jbosna@unizd.hr

Anita Radman Peša

apesa@unizd.hr

Elżbieta Wrońska-Bukalska

elzbieta.bukalska@umcs.lublin.pl

1 Department of Economics, University of Zadar, Splitska 1, 23000 Zadar, Croatia

2 Faculty of Economics, Maria Curie Sklodowska University, Lublin Pl. M. C. Skłodowskiej 5, 20 031 Lublin, Poland 